Terbit online pada laman web jurnal: http://jurnal.iaii.or.id

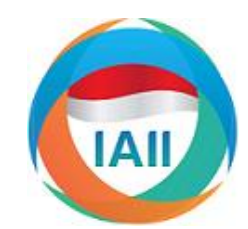

JURNAL, RESTI

(Rekayasa Sistem dan Teknologi Informasi)

Vol. 3 No. 2 (2019) 184 - 189

ISSN Media Elektronik: 2580-0760

\title{
Sistem Pakar Mendiagnosis Penyakit Pada Ikan Gurami Menggunakan Metode Dempster Shafer
}

\author{
Puri Yatna ${ }^{1}$, Yessy Yanitasari ${ }^{2}$, Dedih $^{3}$ \\ ${ }^{1,2}$ Informatika, STMIK Kharisma Karawang \\ ${ }^{3}$ Sistem Informasi, STMIK Kharisma Karawang \\ 1'puriyatna@gmail.com, ${ }^{2}$ yessy.yanitasari@gmai.coml. ${ }^{3}$ dedihthea@gmail.com
}

\begin{abstract}
The limited knowledge possessed by gouramy cultivators on diseases that attack gouramy has become a problem and obstacle in the effort of hatchery and enlargement of gouramy and the lack of experts in gouramy to provide counseling about gouramy diseases, so it is necessary to develop expert system applications aimed at a forum for consultation with experts, diagnosing gouramy disease and providing solutions to prevent diseases of gouramy. In the expert system there are several inference machines that can be used, one of them is using dempster shafers which are mathematical theories for proof based on belief functions and plausible reasoning. Used to calculate the probability of an event obtained from a combination of separate pieces of information (facts). In this study an expert system for diagnosing disease in gouramy using a dempster shafer inference machine resulted in a calculation of the level of confidence in carp disease at the highest $99.85 \%$ in Red Disease (Motile Aeromonas Septocemia) and at least $90 \%$ in white spot disease (White spot).
\end{abstract}

Keywords: Expert System, Cultivator, Gurami Fish, Disease, Dempster Shafer

\begin{abstract}
Abstrak
Terbatasnya pengetahuan yang dimiliki oleh pembudidaya ikan gurami terhadap penyakit yang menyerang ikan gurami menjadi masalah dan kendala dalam usaha pembenihan dan perbesaran ikan gurami serta kurangnya jumlah tenaga pakar ikan gurami untuk memberikan penyuluhan tentang penyakit ikan gurami, maka itu perlu dibangun aplikasi sistem pakar yang bertujuan sebagai wadah konsultasi dengan pakar, mendiagnosis penyakit ikan gurami dan memberikan solusi pencegahan penyakit ikan gurami. Dalam sistem pakar terdapat beberapa mesin inferensi yang dapat digunakan, salah satunya dengan menggunakan dempster shafer yang merupakan teori matematika untuk pembuktian berdasarkan belief functions (fungsi kepercayaan) dan plausible reasoning (penalaran yang masuk akal). Digunakan untuk mengkalkulasi kemungkinan dari suatu peristiwa yang didapat dari kombinasi potongan informasi (fakta) yang terpisah. Dalam penelitian ini dibuat aplikasi sistem pakar diagnosa penyakit pada ikan gurami menggunakan mesin inferensi dempster shafer menghasilkan perhitungan tingkat keyakinan terhadap penyakit ikan gurame paling tinggi $99.85 \%$ pada penyakit Penyakit Merah (Motile Aeromonas Septocemia) dan paling rendah $90 \%$ pada penyakit Bintik putih (White spot).
\end{abstract}

Kata kunci: Sistem Pakar, Pembudidaya, Ikan Gurami, Penyakit, Dempster Shafer

(C) 2019 Jurnal RESTI

\section{Pendahuluan}

Sistem pakar merupakan sistem komputer yang berbasis pada pengetahuan yang terpadu di dalam suatu sistem informasi dasar yang ada, sehingga memiliki kemampuan untuk menyelesaikan masalah dalam bidang tertentu secara cerdas dan efektif, sebagaimana layaknya seorang pakar. Tujuan perancangan sistem pakar adalah untuk mempermudah kerja atau bahkan mengganti tenaga ahli, menggabungkan ilmu dan pengalaman dari beberapa tenaga ahli, dan menyediakan keahlian yang diperlukan suatu proyek yang tidak memiliki tenaga ahli [1]. Sistem pakar mengandung pengetahuan dan pengalaman satu atau banyak pakar yang ditransformasikan kedalam suatu area pengetahuan tertentu sehingga dapat membantu banyak orang dalam memecahkan berbagai macam masalah yang bersifat spesifik [2]. Dalam sistem pakar terdapat beberapa mesin inferensi yang dapat digunakan, salah satunya dengan menggunakan

Diterima Redaksi : 28-05-2019 | Selesai Revisi : 06-07-2019 | Diterbitkan Online : 02-08-2019 
dempster shafer yang merupakan teori matematika dilakukan oleh Yusnita dan Aprilianto (2015) [11] untuk pembuktian berdasarkan belief functions (fungsi untuk diagnosa penyakit ikan nila dengan hasil kepercayaan) dan plausible reasoning (penalaran yang keakurasian sebesar 100\%. selanjutnya oleh Mutaqqin masuk akal). Digunakan untuk mengkalkulasi dkk (2017) [12] diagnosis penyakit ikan koi dengan kemungkinan dari suatu peristiwa yang didapat dari tingkat keberhasilan 95\%. Penelitian selanjutnya oleh kombinasi potongan informasi (fakta) yang terpisah Tumingan dkk (2017) [13] untuk menentukan penyakit [3]. Penerapan metode dempster shafer dalam sistem hernia dengan hasil diagnosa yang memiliki tingkat pakar dapat digunakan untuk persoalan di berbagai kepercayaan atau kepastian YA (bernilai 1) yaitu paling bidang, dan dalam penelitian ini akan digunakan untuk tinggi $90 \%$ dan paling rendah $50 \%$ terhadap masingmendiagnosis penyakit pada ikan gurami. Ikan gurami masing penyakit hernia.

(Osphronemus gouramy) merupakan salah satu dari 15 jenis komoditas perikanan yang ditujukan untuk meningkatkan produksi dan pendapatan petani serta memenuhi sasaran peningkatan gizi masyarakat [4]. Gurami jenis ikan air tawar yang banyak digemari oleh masyarakat dan ikan ini termasuk ikan air tawar konsumsi yang mempunyai nilai ekonomis tinggi [5]. Ikan Gurami mempunyai 8 jenis, masing-masing gurami angsa, gurami jepun, gurami bluesafir, gurame paris, gurame porselin, gurami bastar, gurami kapas, gurami batu [6]. Produksi ikan gurami secara nasional pada tahun 2010 - 2014 menunjukkan kinerja yang positif, dengan kenaikan rata-rata per tahun sebesar $17,70 \%$, sementara tahun 2014 menunjukkan bahwa produksi gurami belum mampu mencapai angka yang ditergetkan dan hanya tercapai $90,15 \%$ begitu juga dengan nilai produksinya yang juga belum mampu mencapai target yang ditetapkan 120.000 ton [7].

Berdasarkan penelitian sebelumnya mendiagnosis penyakit ikan gurami telah diteliti oleh Azizah (2016) [10] dengan meneliti 7 penyakit menggunakan metode forward chaining, untuk penelitian ini akan mendiagnosis penyakit pada ikan gurami dengan 11 penyakit dan 37 gejala, menggunakan metode dempster-shafer. Dengan melibatkan pakar ikan gurami untuk mendapatkan data dan pengetahuan serta solusi penanggulangan pencegahan penyakit pada ikan gurami, untuk kebutuhan dalam membangun sebuah sistem sehingga menghasilkan sistem pakar. Dengan memanfaatkan teknologi informasi yang berkembang pesat seperti sekarang ini, diharapkan pengguna, masyarakat umum terutama pembudidaya dapat lebih mengetahui informasi secara jelas bagaimana cara untuk mengenali gejala-gejala dan mendiagnosis penyakit dan pencegahan penyakit pada ikan gurami. Pendekatan untuk membangun sistem berbasis web Berdasarkan belum tercapainya target produksi ikan yang digunakan adalah System Development Life Cycle gurami yang ditetapkan, disebabkan oleh berbagai (SDLC) Waterfall dengan metode Object Oriented kendala yang mempengaruhi sistem budidaya, Approach (OOA) [14].

diantaranya hama dan penyakit, sistem pemeliharaan,

kualitas benih, nutrisi, dan kualitas air [8]. Pada ikan 2. Metode Penelitian

gurami terdapat 11 jenis penyakit dan 37 gejala penyakit.

Terbatasnya tenaga ahli pakar ikan gurami menyebabkan

\subsection{Metode Dempster-Shafer}

belum meratanya penyuluhan tentang penyakit ikan Teori Dempster-Shafer adalah suatu teori matematika gurami, atas dasar itu para pembudidaya atau petani untuk pembuktian berdasarkan belief functions and tambak kurang pengetahuan terhadap penyakit yang plausible reasoning (fungsi kepercayaan dan pemikiran menyerang ikan gurami tersebut. Dalam permasalahan yang masuk akal), digunakan untuk mengkombinasikan tersebut juga petani kesulitan dalam penanggulangan potongan informasi yang terpisah untuk mengkalkulasi maupun cara pengobatannya. Atas dasar itu dibutuhkan kemungkinan dari suatu peristiwa. Ditulis dalam suatu peran yang dapat memberikan solusi dalam mengatasi interval: [Belief, Plausibility] [15,16]. Belief (Bel) adapenyakit, dan bagaimana cara penanggulangannya, lah ukuran kekuatan evidence (gejala) dalam mendengan adanya seorang pakar perikanan sebagai tempat dukung suatu himpunan bagian. Jika bernilai 0 maka konsultasi [9]. Penelitian dengan topik penyakit pada mengindikasikan bahwa tidak ada evidence, dan jika ikan gurami (Osphronemus gouramy) telah dilakukan bernilai 1 menunjukan adanya kepastian. Plausibility sebelumnya oleh Azizah (2016) [10] menggunakan (Pl) dinotasikan sebagai: Pl(s) = 1 - Bel(-s). Plausibilmetode forward chainning untuk mendiagnosis ity juga bernilai 0 sampai 1 . Jika kita yakin akan $-\mathrm{s}$, penyakit pada ikan gurami meneliti 7 penyakit. maka dapat dikatakan bahwa $\operatorname{Bel}(\neg \mathrm{s})=1, \operatorname{dan} \operatorname{Pl}(\neg \mathrm{s})=$ Selanjutnya oleh Priyambodo (2017) [8] untuk 0. Plausability akan mengurangi tingkat kepercayaan pengaruh pemberian ekstrak alga cokelat terhadap dari evidence. Pada teori Dempster-Shafer kita kadar hematokrit, leukokrit, aglutinasi dengan bakteri mengenal adanya frame of discernment yang dinotasidan superoksida anion pada ikan gurami, dengan hasil kan dengan $\Theta$ dan mass function yang dinotasikan penelitian menunjukan bahwa dengan penambahan dengan $m$. Frame ini merupakan semesta pembicaraan ekstra Padina sp pada pakan berpengaruh terhadap dari sekumpulan hipotesis sehingga disebut dengan hematokrit dan leukokrit, aglutinasi dengan bakteri dan environtment.

Superoksida anion ikan gurami. Sedangkan untuk penelitian dengan metode dempster shafer telah 


$$
m 3(Z)=\frac{\sum x \cap Z^{m 1(x) m 2(y)}}{1-k}
$$

Keterangan :

$\mathrm{ml}(\mathrm{X})$ adalah mass function dari evidence $\mathrm{X}$ $\mathrm{m} 2(\mathrm{Y})$ adalah mass function dari evidence $\mathrm{Y}$ $\mathrm{m} 3(\mathrm{Z})$ adalah mass function dari evidence $\mathrm{Z}$ $\mathrm{K}$ adalah jumlah conflict evidence

Sedangkan mass function (m) dalam teori DempsterShafer adalah tingkat kepercayaan dari suatu evidence measure sehingga dinotasikan dengan (m). Untuk mengatasi sejumlah evidence pada teori dempsterShafer menggunakan aturan yang lebih dikenal dengan Dempster's Rule of Combination.

$$
K=\sum X \cap Y=\emptyset m 1(X) m 2(Y)
$$

Keterangan :

$\mathrm{m} 1$ (X) adalah mass function dari evidence $\mathrm{X}$ $\mathrm{m} 2(\mathrm{Y})$ adalah mass function dari evidence $\mathrm{Y}$ $\mathrm{K}$ adalah jumlah conflict evidence

2.2. Data gejala \& jenis penyakit pada ikan gurami.

Ada 37 gejala penyakit pada ikan gurami pada tabel 1

\begin{tabular}{|c|c|}
\hline $\begin{array}{l}\text { Kode } \\
\text { Gejala }\end{array}$ & Hasil Gejala Penyakit Ikan gurami \\
\hline G01 & Nafsu makan ikan menurun \\
\hline G02 & Warna tubuh gelap atau pucat \\
\hline G03 & $\begin{array}{l}\text { Frekwensi pernapasan meningkat ikan mengap- } \\
\text { mengap }\end{array}$ \\
\hline G04 & Sering meloncat-loncat kepermukaan air \\
\hline G05 & Ikan berenang lamban \\
\hline G06 & Ikan menggosok-gosokan badan pada benda sekitar \\
\hline G07 & Ikan memproduksi lendir berlebih \\
\hline G08 & Ikan tampak kurus \\
\hline G09 & Terdapat Iritasi pada ikan, luka kulit \\
\hline G10 & $\begin{array}{l}\text { Pendarahan pada pangkal sirip, ekor, sekitar anus } \\
\text { dan bagian tubuh lainnya }\end{array}$ \\
\hline G11 & $\begin{array}{l}\text { Luka disekitar mulut, kepala, badan atau sirip, luka } \\
\text { berwarna putih kecoklatan kemudian berkembang } \\
\text { menjadi borok }\end{array}$ \\
\hline G12 & Ikan berenang kepermukaan (hiperaktif) \\
\hline G13 & Bintik-bintik merah pada permukaan tubuh \\
\hline G14 & Bintik merah berkembang menjadi luka atau borok \\
\hline G15 & $\begin{array}{l}\text { Terlihat adanya benang-benang halus menyerupai } \\
\text { kapas yang menempel pada telura tau luka pada } \\
\text { bagian eksternal tubuh ikan }\end{array}$ \\
\hline G16 & Misela, kumpulnya hifa berwarna putih kecoklatan \\
\hline G17 & Bintik-bintik putih disirip, kulit dan insang \\
\hline G18 & Sirip rusak menguncup/ rontok \\
\hline G19 & $\begin{array}{l}\text { Terdapat benjolan putih seperti tumor berbentuk } \\
\text { bulat lonjong menyerupai padi pada insang ikan }\end{array}$ \\
\hline G20 & $\begin{array}{l}\text { Ikan bengkak-bengkak/gembil pada bagian tubuh } \\
\text { (kanan/kiri) }\end{array}$ \\
\hline G21 & Berenang tidak normal \\
\hline $\mathrm{G} 22$ & $\begin{array}{l}\text { Insang pucat/membengkak sehingga operkulum } \\
\text { terbuka }\end{array}$ \\
\hline $\mathrm{G} 23$ & Produksi mukus pada pada insang berlebih \\
\hline $\mathrm{G} 24$ & Ikan tampak lemah \\
\hline G25 & $\begin{array}{l}\text { Peradangan pada kulit disertai warna kemerahan } \\
\text { pada badan }\end{array}$ \\
\hline G26 & Pertumbuhan ikan lambat \\
\hline
\end{tabular}
dan 11 penyakit pada ikan gurami pada tabel 2 .

\begin{tabular}{cl}
\hline $\begin{array}{c}\text { Kode } \\
\text { Gejala }\end{array}$ & \multicolumn{1}{c}{ Hasil Gejala Penyakit Ikan gurami } \\
\hline G27 & Hilang keseimbangan \\
G28 & Berenang zigzag \\
G29 & Terdapat kutu yang menempel pada tubuh ikan \\
G30 & Luka tertutup oleh pigmen berwarna kuning cerah \\
G31 & Sisik ikan lepas \\
G32 & Perut lembek dan bengkak yang berisis cairan \\
& merah kekuningan \\
G33 & Ikan mengumpul dekat dengan saluran pembuangan \\
G34 & Infeksi disekitar mulut, terlihat seperti diselaputi \\
& benang disebut jamur mulut \\
G35 & Mata ikan melotot \\
G36 & Sisik patah-patah \\
G37 & Pembengkakan empedu, ginjal, hati \\
& \\
& Tabel 2 Jenis Penyakit Pada Ikan Gurami \\
\hline Kode & \\
\hline P1 & Epizotic Ulcerative Syndrome (EUS) \\
P2 & Saprolegniasis \\
P3 & Bintik putih (White spot) \\
P4 & Gatal (Trichodiniasis) \\
P5 & Penyakit Gembil (Myxosporidiasis) \\
P6 & Cacing Insang (Dactylogyriaris) \\
P7 & Cacing Kulit (Gyrodactyliasis) \\
P8 & Kutu ikan (argulosis) \\
P9 & Penyakit Merah (Motile Aeromonas Septocemia) \\
P10 & Columnaris Disease \\
P11 & Mycobacteriosis/Fish Tuberculosis (TB) \\
\hline & \\
\hline & \\
&
\end{tabular}

\section{Hasil dan Pembahasan}

Hasil perhitungan metode Dempster-Shafer dari setiap gejala yang ditimbulkan terhadap penyakit ikan gurame.

\subsection{Menentukan nilai belief (bel)}

Data nilai ini digunakan untuk mengetahui ukuran kekuatan dalam suatu gejala pada penyakit gurami yang ditetapkan oleh pakar sehingga dalam hal pendiagnosaan memudahkan untuk menunjukan adanya kepastian.

Tabel 3 Penentuan Nilai belief Pada Penyakit Ikan Gurami

\begin{tabular}{cccc}
\hline Kode & Nilai Belief & Kode & Nilai Belief \\
\hline G01 & 0.8 & G20 & 0.8 \\
G02 & 0.6 & G21 & 0.7 \\
G03 & 0.6 & G22 & 0.8 \\
G04 & 0.7 & G23 & 0.8 \\
G05 & 0.5 & G24 & 0.7 \\
G06 & 0.7 & G25 & 0.9 \\
G07 & 0.6 & G26 & 0.7 \\
G08 & 0.7 & G27 & 0.6 \\
G09 & 0.7 & G28 & 0.8 \\
G10 & 0.7 & G29 & 0.9 \\
G11 & 0.8 & G30 & 0.8 \\
G12 & 0.6 & G31 & 0.7 \\
G13 & 0.9 & G32 & 0.7 \\
G14 & 0.9 & G33 & 0.8 \\
G15 & 0.8 & G34 & 0.8 \\
G16 & 0.8 & G35 & 0.8 \\
G17 & 0.9 & G36 & 0.8 \\
G18 & 0.9 & G37 & 0.9 \\
G19 & 0.9 & & \\
\hline
\end{tabular}

3.2. Menentukan nilai Plausibility (Pl)

Dinotasikan sebagai : $\mathrm{Pl}=1-$ Belief 
Tabel 4 Penentuan Nilai plausibility Pada Penyakit Ikan Gurami

\begin{tabular}{cccccc}
\hline Kode & $\begin{array}{c}\text { Nilai } \\
\text { Belief }\end{array}$ & $\begin{array}{c}\text { Nilai } \\
\text { Plausibility }\end{array}$ & Kode & $\begin{array}{c}\text { Nilai } \\
\text { Belief }\end{array}$ & $\begin{array}{c}\text { Nilai } \\
\text { Plausibility }\end{array}$ \\
\hline G01 & 0.8 & 0.2 & G20 & 0.8 & 0.2 \\
G02 & 0.6 & 0.4 & G21 & 0.7 & 0.3 \\
G03 & 0.6 & 0.4 & G22 & 0.8 & 0.2 \\
G04 & 0.7 & 0.3 & G23 & 0.8 & 0.2 \\
G05 & 0.5 & 0.5 & G24 & 0.7 & 0.3 \\
G06 & 0.7 & 0.3 & G25 & 0.9 & 0.1 \\
G07 & 0.6 & 0.4 & G26 & 0.7 & 0.3 \\
G08 & 0.7 & 0.3 & G27 & 0.6 & 0.4 \\
G09 & 0.7 & 0.3 & G28 & 0.8 & 0.2 \\
G10 & 0.7 & 0.3 & G29 & 0.9 & 0.1 \\
G11 & 0.8 & 0.2 & G30 & 0.8 & 0.2 \\
G12 & 0.6 & 0.4 & G31 & 0.7 & 0.3 \\
G13 & 0.9 & 0.1 & G32 & 0.7 & 0.3 \\
G14 & 0.9 & 0.1 & G33 & 0.8 & 0.2 \\
G15 & 0.8 & 0.2 & G34 & 0.8 & 0.2 \\
G16 & 0.8 & 0.2 & G35 & 0.8 & 0.2 \\
G17 & 0.9 & 0.1 & G36 & 0.8 & 0.2 \\
G18 & 0.9 & 0.1 & G37 & 0.9 & 0.1 \\
G19 & 0.9 & 0.1 & & & \\
\hline
\end{tabular}

\subsection{Menentukan dempster's rule of combination}

Perhitungan untuk penyakit P01 yaitu Epizotic Ulceratif Syndrom (EUS) dihitung dari setiap gejala yang ditimbulkan, dimana untuk menghitung dempster's rule of combination dibutuhkan dua gejala. Berikut adalah perhitungannya:

G01 : Nafsu makan ikan menurun

Langkah pertama hitung nilai dari belief dan plausibility dari (G01), yang merupakan gejala dari penyakit $\mathrm{P} 1, \mathrm{P} 2, \mathrm{P} 3, \mathrm{P} 4, \mathrm{P} 6, \mathrm{P} 7, \mathrm{P} 9, \mathrm{P} 11$

$\mathrm{m} 1\{\mathrm{P} 1, \mathrm{P} 2, \mathrm{P} 3, \mathrm{P} 4, \mathrm{P} 6, \mathrm{P} 7, \mathrm{P} 9, \mathrm{P} 11\}=0.8$

$$
\begin{aligned}
\mathrm{m} 1\{\odot\} & =1-\mathrm{m} 1 \\
& =1-0.8 \\
& =0.2
\end{aligned}
$$

G02: Warna tubuh ikan gelap atau pucat

Hitung nilai dari belief dan plausibility dari (G02) yang merupakan diagnosa dari penyakit P1, P4, P6, P7, P9

$\mathrm{m} 2\{\mathrm{P} 1, \mathrm{P} 4, \mathrm{P} 6, \mathrm{P} 7, \mathrm{P} 9\}=0.6$

$$
\begin{aligned}
\mathrm{m} 2\{\Theta\} & =1-\mathrm{m} 2 \\
& =1-0.6 \\
& =0.4
\end{aligned}
$$

Perhitungan $\mathrm{m} 1$ dan $\mathrm{m} 2$ dilakukan sebagai berikut:

a. $\mathrm{m} 1\{\mathrm{P} 1, \mathrm{P} 2, \mathrm{P} 3, \mathrm{P} 4, \mathrm{P} 6, \mathrm{P} 7, \mathrm{P} 9, \mathrm{P} 11\}=0.8$

b. $\mathrm{m} 1\{\odot\}=1-\mathrm{m} 1=0.2$

c. $\mathrm{m} 2\{\mathrm{P} 1, \mathrm{P} 4, \mathrm{P} 6, \mathrm{P} 7, \mathrm{P} 9\}=0.6$

d. $\mathrm{m} 2\{\odot\}=1=0.4$

Dimana $\mathrm{m} 1$ dan $\mathrm{m} 2$ mengacu pada gejala pertama dan $\mathrm{m} 5\{\mathrm{P} 1, \mathrm{P} 2, \mathrm{P} 3, \mathrm{P} 4, \mathrm{P} 6, \mathrm{P} 7, \mathrm{P} 9, \mathrm{P} 11\}$ gejala kedua.

Tabel 5 Kombinasi dari $\mathrm{m} 1$ dan $\mathrm{m} 2$

\begin{tabular}{lcc}
\hline & $\mathrm{m} 2\{\mathrm{P} 1, \mathrm{P} 4, \mathrm{P} 6, \mathrm{P} 7, \mathrm{P} 9\}$ & $\mathrm{m} 2\{\odot\}$ \\
\hline $\mathrm{m} 1$ & $\{\mathrm{P} 1, \mathrm{P} 4, \mathrm{P} 6, \mathrm{P} 7, \mathrm{P} 9\}$ & $\{\mathrm{P} 1, \mathrm{P} 2, \mathrm{P} 3, \mathrm{P} 4, \mathrm{P} 6$, \\
$\{\mathrm{P} 1, \mathrm{P} 2, \mathrm{P} 3, \mathrm{P} 4, \mathrm{P} 6$ & & $\mathrm{P} 7, \mathrm{P} 9, \mathrm{P} 11\}$ \\
,P7,P9,P11 & & \\
$\mathrm{m} 1\{\Theta\}$ & $\{\mathrm{P} 1, \mathrm{P} 4, \mathrm{P} 6, \mathrm{P} 7, \mathrm{P} 9\}$ & $\{\odot\}$ \\
$\mathrm{m} 1\{\mathrm{P} 1, \mathrm{P} 2, \mathrm{P} 3, \mathrm{P} 4$ & 0.48 & 0.32 \\
,P6,P7,P9,P11 & & \\
$\mathrm{m} 1\{\odot\}$ & 0.12 & 0.08 \\
\hline
\end{tabular}

$\mathrm{m} 3\{\mathrm{P} 1, \mathrm{P} 4, \mathrm{P} 6, \mathrm{P} 7, \mathrm{P} 9\}=\mathrm{m} 1 * \mathrm{~m} 2(\mathrm{P} 1, \mathrm{P} 4, \mathrm{P} 6, \mathrm{P} 7, \mathrm{P} 9)$

$$
=\frac{0.48+0.12}{1-0}=\mathbf{0 . 6}
$$

$\mathrm{m} 3\{\mathrm{P} 1, \mathrm{P} 2, \mathrm{P} 3, \mathrm{P} 4, \mathrm{P} 6, \mathrm{P} 7, \mathrm{P} 9, \mathrm{P} 11\}$

$=\mathrm{m} 1 * \mathrm{~m} 2(\mathrm{P} 1, \mathrm{P} 2, \mathrm{P} 3, \mathrm{P} 4, \mathrm{P} 6, \mathrm{P} 7, \mathrm{P} 9, \mathrm{P} 11)$

$=\frac{0.32}{1-0}=\mathbf{0 . 3 2}$

$\mathrm{m} 3\{\odot\}=\mathrm{m} 1 * \mathrm{~m} 2(\odot)=\frac{0.008}{1-0}=\mathbf{0 . 0 8}$

Jadi nilai dari kombinasi dua gejala yang ada, dengan nilai $\mathrm{m} 3$ tertinggi yaitu $\mathrm{m} 3=(0.6)$ kemungkinan teridentifikasi penyakit $\mathrm{P} 1, \mathrm{P} 4, \mathrm{P} 6, \mathrm{P} 7, \mathrm{P} 9$ dengan nilai presentase $(0.6 * 100 \%)=60 \%$.

Jika terdapat gejala selanjutnya ikan berenang kepermukaan hiperaktif, maka menghitung kombinasi tiga gejala. Untuk menghitung kombinasi tiga gejala memerlukan nilai dari kombinasi dari dua gejala.

G12: Ikan berenang kepermukaan hiperaktif

Hitung nilai dari belief dan plausability dari (G12) yang merupakan diagnosa dari penyakit P1
$\mathrm{m} 4\{\mathrm{P} 1\}$
$=0.6$
$\mathrm{m} 4\{\odot\} \quad=1-\mathrm{m} 4=0.4$

Perhitungan $\mathrm{m} 3$ dan $\mathrm{m} 4$ dilakukan sebagai berikut :
a. $\mathrm{m} 3\{\mathrm{P} 1, \mathrm{P} 4, \mathrm{P} 6, \mathrm{P} 7, \mathrm{P} 9\} \quad=0.6$
b. $\mathrm{m} 3\{\mathrm{P} 1, \mathrm{P} 2, \mathrm{P} 3, \mathrm{P} 4, \mathrm{P} 6, \mathrm{P} 7, \mathrm{P} 9, \mathrm{P} 11\}=0.32$

\begin{tabular}{|c|c|c|}
\hline & $\mathrm{m} 4\{\mathrm{P} 1)$ & $\mathrm{m} 4\{\odot\}$ \\
\hline m3 \{P1,P4,P6,P7,P9\} & $\{\mathrm{P} 1\}$ & $\{\mathrm{P} 1, \mathrm{P} 4, \mathrm{P} 6, \mathrm{P} 7, \mathrm{P} 9\}$ \\
\hline $\mathrm{m} 3\{\mathrm{P} 1, \mathrm{P} 2, \mathrm{P} 3, \mathrm{P} 4, \mathrm{P} 6, \mathrm{P} 7, \mathrm{P} 9$ & $\{\mathrm{P} 1\}$ & \\
\hline ,P11\} & & $\begin{array}{l}\text { P1,P2,P3,P4,P6,P7,P } \\
\text { 9,P11\} }\end{array}$ \\
\hline $\mathrm{m} 3\{\odot\}$ & $\{\mathrm{P} 1\}$ & $\{\odot\}$ \\
\hline m3 \{P1,P4,P6,P7,P9\} & 0.36 & 0.24 \\
\hline $\begin{array}{l}\mathrm{m} 3\{\mathrm{P} 1, \mathrm{P} 2, \mathrm{P} 3, \mathrm{P} 4, \mathrm{P} 6, \mathrm{P} 7, \mathrm{P} 9 \\
\text {,P11\} }\end{array}$ & 0.192 & 0.128 \\
\hline $\mathrm{m} 3\{\odot\}$ & 0.05 & 0.032 \\
\hline
\end{tabular}
c. $\mathrm{m} 3\{\odot\} \quad=0.08$
d. $\mathrm{m} 4\{\mathrm{P} 1\} \quad=0.6$
e. $\mathrm{m} 4\{\odot\}$
$=1-\mathrm{m} 4=0.4$

Dimana $\mathrm{m} 4$ adalah gejala ke tiga

Tabel 6 Kombinasi dari $\mathrm{m} 3$ dan $\mathrm{m} 4$

$\mathrm{m} 5\{\mathrm{P} 1\}=\mathrm{m} 3 * \mathrm{~m} 4(\mathrm{P} 1)=\frac{0.36+0.192+0.048}{1-0}=\mathbf{0 . 6}$

$\mathrm{m} 5\{\mathrm{P} 1, \mathrm{P} 4, \mathrm{P} 6, \mathrm{P} 7, \mathrm{P} 9\}=\mathrm{m} 3 * \mathrm{~m} 4(\mathrm{P} 1, \mathrm{P} 4, \mathrm{P} 6, \mathrm{P} 7, \mathrm{P} 9)$

$$
=\frac{0.24}{1-0}=\mathbf{0 . 2 4}
$$

$=\mathrm{m}_{0.128} \mathrm{~m} 4(\mathrm{P} 1, \mathrm{P} 2, \mathrm{P} 3, \mathrm{P} 4, \mathrm{P} 6, \mathrm{P} 7, \mathrm{P} 9, \mathrm{P} 11)$

$=\frac{0.128}{1-0}=\mathbf{0 . 1 2 8}$

$\mathrm{m} 5\{\odot\}=\mathrm{m} 3 * \mathrm{~m} 4(\odot)=\frac{0.032}{1-0}=\mathbf{0 . 0 3 2}$

Jadi nilai dari kombinasi tiga gejala yang ada, dengan nilai $\mathrm{m} 5$ tertinggi yaitu $\mathrm{m} 5=(0.6)$ kemungkinan 
teridentifikasi penyakit $\mathrm{P} 1$ dengan nilai presentase $(0.6 \mathrm{~m} 8\{\mathrm{P} 1\}=0.9$

$* 100 \%)=60 \%$.

$\mathrm{m} 8\{\odot\}=1-\mathrm{m} 8=0.1$

Jika terdapat gejala selanjutnya bintik-bintik merah pada Perhitungan $\mathrm{m} 5$ dan $\mathrm{m} 6$ dilakukan sebagai berikut : permukaan tubuh, maka menghitung kombinasi empat a. $\mathrm{m} 7\{\mathrm{P} 1\} \quad 0.96$ gejala. Untuk menghitung kombinasi empat gejala b. $\mathrm{m} 7\{\mathrm{P} 1, \mathrm{P} 4, \mathrm{P} 6, \mathrm{P} 7, \mathrm{P} 9\} \quad=0.024$ memerlukan nilai dari kombinasi dari tiga gejala.

c. $\mathrm{m} 7\{\mathrm{P} 1, \mathrm{P} 2, \mathrm{P} 3, \mathrm{P} 4, \mathrm{P} 6, \mathrm{P} 7, \mathrm{P} 9, \mathrm{P} 11\}$

$=0.0128$

G13: Bintik-bintik merah pada permukaan tubuh

d. $\mathrm{m} 7\{\odot\}$

$=0.0032$

Hitung nilai dari belief dan plausability dari G13 yang merupakan diagnosa dari penyakit $\mathrm{P} 1$

e. $\mathrm{m} 8\{\mathrm{P} 1\}$

$=0.9$

f. $m 8\{\odot\}$

$=1-\mathrm{m} 8=0.1$

$\mathrm{m} 6\{\mathrm{P} 1\}=0.9$

$\mathrm{m} 6\{\odot\}=1-\mathrm{m} 6=0.1$

Perhitungan $\mathrm{m} 5$ dan $\mathrm{m} 6$ dilakukan sebagai berikut :
a. $\mathrm{m} 5\{\mathrm{P} 1\}$
b. $\mathrm{m} 5\{\mathrm{P} 1, \mathrm{P} 4, \mathrm{P} 6, \mathrm{P} 7, \mathrm{P} 9\}$
$=0.6$
c. $\mathrm{m} 5\{\mathrm{P} 1, \mathrm{P} 2, \mathrm{P} 3, \mathrm{P} 4, \mathrm{P} 6, \mathrm{P} 7, \mathrm{P} 9, \mathrm{P} 11\}$
$=0.24$
d. $\mathrm{m} 5\{\odot\}$
e. $\mathrm{m} 6\{\mathrm{P} 1\}$
f. $\mathrm{m} 6\{\odot\}$
$=0.128$
$=0.032$
$=0.9$
$=1-\mathrm{m} 6=0.1$

Dimana m6 merupakan gejala ke empat

Tabel 7 Kombinasi dari m5 dan m6

\begin{tabular}{lcl}
\hline & $\mathrm{m} 6\{\mathrm{P} 1\}$ & \multicolumn{1}{c}{$\mathrm{m}_{6}\{\mathrm{\Theta}\}$} \\
\hline $\mathrm{m} 5\{\mathrm{P} 1\}$ & $\{\mathrm{P} 1\}$ & $\{\mathrm{P} 1\}$ \\
$\mathrm{m} 5\{\mathrm{P} 1, \mathrm{P} 4, \mathrm{P} 6, \mathrm{P} 7, \mathrm{P} 9\}$ & $\{\mathrm{P} 1\}$ & $\{\mathrm{P} 1, \mathrm{P} 4, \mathrm{P} 6, \mathrm{P} 7, \mathrm{P} 9\}$ \\
$\mathrm{m} 5\{\mathrm{P} 1, \mathrm{P} 2, \mathrm{P} 3, \mathrm{P} 4, \mathrm{P} 6, \mathrm{P} 7$ & $\{\mathrm{P} 1\}$ & $\{\mathrm{P} 1, \mathrm{P} 2, \mathrm{P} 3, \mathrm{P} 4, \mathrm{P} 6, \mathrm{P}$ \\
,P9,P11 & \multicolumn{2}{c}{$7, \mathrm{P} 9, \mathrm{P} 11\}$} \\
$\mathrm{m} 5\{\odot\}$ & $\{\mathrm{P} 1\}$ & $\{\odot\}$ \\
m5 $\{\mathrm{P} 1\}$ & $\mathbf{0 . 5 4}$ & $\mathbf{0 . 0 6}$ \\
m5 $\{\mathrm{P} 1, \mathrm{P} 4, \mathrm{P} 6, \mathrm{P} 7, \mathrm{P} 9\}$ & $\mathbf{0 . 2 1 6}$ & $\mathbf{0 . 0 2 4}$ \\
m5 $\{\mathrm{P} 1, \mathrm{P} 2, \mathrm{P} 3, \mathrm{P} 4, \mathrm{P} 6, \mathrm{P} 7$ & $\mathbf{0 . 1 1 5 2}$ & $\mathbf{0 . 0 1 2 8}$ \\
,P9,P11 & & \\
m5 $\{\mathrm{\Theta}\}$ & $\mathbf{0 . 0 2 8 8}$ & $\mathbf{0 . 0 0 3 2}$ \\
\hline
\end{tabular}

$\mathrm{m} 7\{\mathrm{P} 1\}=\mathrm{m} 5 * \mathrm{~m} 6(\mathrm{P} 1)$

$$
=\frac{0.54+0.216+0.1152+0.0288+0.06}{1-0}=\mathbf{0 . 9 6}
$$

$\mathrm{m} 7\{\mathrm{P} 1, \mathrm{P} 4, \mathrm{P} 6, \mathrm{P} 7, \mathrm{P} 9\}=\mathrm{m} 5 * \mathrm{~m} 6(\mathrm{P} 1, \mathrm{P} 4, \mathrm{P} 6, \mathrm{P} 7, \mathrm{P} 9)$

$$
=\frac{0.024}{1-0}=\mathbf{0 . 0 2 4}
$$

$\mathrm{m} 7\{\mathrm{P} 1, \mathrm{P} 2, \mathrm{P} 3, \mathrm{P} 4, \mathrm{P} 6, \mathrm{P} 7, \mathrm{P} 9, \mathrm{P} 11\}$

$=\mathrm{m} 5^{*} \mathrm{~m} 6(\mathrm{P} 1, \mathrm{P} 2, \mathrm{P} 3, \mathrm{P} 4, \mathrm{P} 6, \mathrm{P} 7, \mathrm{P} 9, \mathrm{P} 11)$

$=\frac{0.0128}{1-0}=\mathbf{0 . 0 1 2 8}$

$\mathrm{m} 7\{\odot\}=\mathrm{m} 5 * \mathrm{~m} 6(\odot)=\frac{0.0032}{1-0}=\mathbf{0 . 0 0 3 2}$

Jadi nilai dari kombinasi empat gejala yang ada, dengan nilai $\mathrm{m} 7$ tertinggi yaitu $\mathrm{m} 7=(0.96)$ kemungkinan teridentifikasi penyakit $\mathrm{P} 1$ dengan nilai presentase $(0.96 * 100 \%)=96 \%$.

Jika terdapat gejala selanjutnya bintik merah berkembang menjadi luka atau borok, maka menghitung kombinasi lima gejala. Untuk menghitung kombinasi lima gejala memerlukan nilai dari kombinasi dari empat gejala.

G14: Bintik merah berkembang menjadi luka atau borok

Hitung nilai dari belief dan plausability dari G14 yang merupakan diagnosa dari penyakit P1
Dimana m8 merupakan gejala ke lima

Tabel 8 Kombinasi dari $\mathrm{m} 7 \mathrm{dan} \mathrm{m} 8$

\begin{tabular}{lcl}
\hline & $\mathrm{m} 8\{\mathrm{P} 1\}$ & \multicolumn{1}{c}{$\mathrm{m} 8\{\odot\}$} \\
\hline $\mathrm{m} 7\{\mathrm{P} 1\}$ & $\{\mathrm{P} 1\}$ & $\{\mathrm{P} 1\}$ \\
$\mathrm{m} 7\{\mathrm{P} 1, \mathrm{P} 4, \mathrm{P} 6, \mathrm{P} 7, \mathrm{P} 9\}$ & $\{\mathrm{P} 1\}$ & $\{\mathrm{P} 1 \mathrm{P} 4, \mathrm{P} 6, \mathrm{P} 7, \mathrm{P} 9\}$ \\
$\mathrm{m} 7\{\mathrm{P} 1, \mathrm{P} 2, \mathrm{P} 3, \mathrm{P} 4, \mathrm{P} 6, \mathrm{P} 7$ & $\{\mathrm{P} 1\}$ & $\{\mathrm{P} 1, \mathrm{P} 2, \mathrm{P} 3, \mathrm{P} 4, \mathrm{P} 6, \mathrm{P}$ \\
,P9,P11 & \multicolumn{2}{c}{$7, \mathrm{P} 9, \mathrm{P} 11\}$} \\
$\mathrm{m} 7\{\odot\}$ & $\{\mathrm{P} 1\}$ & $\{\odot\}$ \\
$\mathrm{m} 7\{\mathrm{P} 1\}$ & $\mathbf{0 . 8 6 4}$ & $\mathbf{0 . 9 6}$ \\
$\mathrm{m} 7\{\mathrm{P} 1, \mathrm{P} 4, \mathrm{P} 6, \mathrm{P} 7, \mathrm{P} 9\}$ & $\mathbf{0 . 0 2 1 6}$ & $\mathbf{0 . 0 0 2 4}$ \\
m7 $\{\mathrm{P} 1, \mathrm{P} 2, \mathrm{P} 3, \mathrm{P} 4, \mathrm{P} 6, \mathrm{P} 7$ & $\mathbf{0 . 0 1 1 5 2}$ & $\mathbf{0 . 0 0 1 2 8}$ \\
,P9,P11 & & \\
$\mathrm{m} 7\{\odot\}$ & $\mathbf{0 . 0 0 2 8 8}$ & $\mathbf{0 . 0 0 0 3 2}$ \\
\hline
\end{tabular}

$\mathrm{m} 9\{\mathrm{P} 1\}=\mathrm{m} 7 * \mathrm{~m} 8(\mathrm{P} 1)$

$$
=\frac{0.864+0.0216+0.01152+0.00288+0.096}{1-0}=\mathbf{0 . 9 9 6}
$$

$\mathrm{m} 9\{\mathrm{P} 1, \mathrm{P} 4, \mathrm{P} 6, \mathrm{P} 7, \mathrm{P} 9\}=\mathrm{m} 7 * \mathrm{~m} 8(\mathrm{P} 1, \mathrm{P} 4, \mathrm{P} 6, \mathrm{P} 7, \mathrm{P} 9)$

$$
=\frac{0.0024}{1-0}=\mathbf{0 . 0 0 2 4}
$$

$\mathrm{m} 9\{\mathrm{P} 1, \mathrm{P} 2, \mathrm{P} 3, \mathrm{P} 4, \mathrm{P} 6, \mathrm{P} 7, \mathrm{P} 9, \mathrm{P} 11\}$

$=\mathrm{m} 7 * \mathrm{~m} 8(\mathrm{P} 1, \mathrm{P} 2, \mathrm{P} 3, \mathrm{P} 4, \mathrm{P} 6, \mathrm{P} 7, \mathrm{P} 9, \mathrm{P} 11$

$=\frac{0.00128}{1-0}=\mathbf{0 . 0 0 1 2 8}$

$\mathrm{m} 9\{\odot\}=\mathrm{m} 7 * \mathrm{~m} 8(\odot)=\frac{0.00032}{1-0}=\mathbf{0 . 0 0 0 3 2}$

Dengan demikian, disimpulkan bahwa hasil diagnosis adalah penyakit Epizotic Ulceratif Syndrom (EUS) dengan nilai $99.60 \%$.

Untuk nilai penyakit dari P2 sampai p11 cara perhitungan kedalam dempster shafer sama hal nya dengan perhitungan yang dilakukan P1. Dibawah ini tabel hasil akhir perhitungan dari setiap penyakit.

\begin{tabular}{clc}
\multicolumn{3}{c}{ Tabel 9 hasil perhitungan dempster shafer P1 sampai P11 } \\
\hline $\begin{array}{c}\text { Kode } \\
\text { Penyakit }\end{array}$ & \multicolumn{1}{c}{ Nama Penyakit } & $\begin{array}{c}\text { Hasil } \\
\text { Perhitungan } \\
\text { Dempster } \\
\text { Shafer (\%) }\end{array}$ \\
\hline P1 & Epizotic Ulcerative Syndrome & 99.60 \\
& (EUS) & \\
P2 & Saprolegniasis & 96 \\
P3 & Bintik putih (White spot) & 90 \\
P4 & Gatal (Trichodiniasis) & 99.81 \\
P5 & Penyakit Gembil & 99.4 \\
(Myxosporidiasis) & 96 \\
P6 & Cacing Insang & 99.1 \\
\hline P7 & (Dactylogyriaris) & \\
\hline
\end{tabular}




\begin{tabular}{clc}
\hline $\begin{array}{c}\text { Kode } \\
\text { Penyakit }\end{array}$ & \multicolumn{1}{c}{ Nama Penyakit } & $\begin{array}{c}\text { Hasil } \\
\text { Perhitungan } \\
\text { Dempster } \\
\text { Shafer (\%) }\end{array}$ \\
\hline P8 & Kutu ikan (argulosis) & 99.2 \\
P9 & $\begin{array}{l}\text { Penyakit Merah (Motile } \\
\text { Aeromonas Septocemia) }\end{array}$ & 99.85 \\
P10 & $\begin{array}{l}\text { Columnaris Disease } \\
\text { Mycobacteriosis/Fish } \\
\text { P11 }\end{array}$ & 96 \\
& Tuberculosis (TB) & 99.6 \\
\hline
\end{tabular}

Hasil dari penelitian sistem pakar mendiagnosis penyakit pada ikan gurami yang pernah dilakukan sebelumnya dilakukan oleh Azizah (2016) [10] menghasilkan tingkat akurasi $90 \%$ dengan menggunakan metode forward chaining terhadap 7 penyakit, sedangkan hasil penelitian yang telah dilakukan oleh kami menghasilkan tingkat akurasi keyakinan terhadap penyakit ikan gurami paling tinggi $99.85 \%$ dan paling rendah $90 \%$ terhadap 11 penyakit dengan menggunakan metode dempster shafer.

\section{Kesimpulan}

Sistem pakar mendiagnosis penyakit ikan gurami menggunakan perhitungan metode dempster shafer menghasilkan tingkat keyakinan terhadap penyakit ikan gurami paling tinggi $99.85 \%$ pada penyakit Penyakit Merah (Motile Aeromonas Septocemia) dan paling rendah $90 \%$ pada penyakit Bintik putih (White spot).

\section{Ucapan Terimakasih}

Bapak Nur Ridwan Solihin S.PKP M.M. Sebagai pakar dibidang pengawas dan pengendali penyakit ikan, Dinas Perikanan dan Kelautan Kabupaten Karawang.

\section{Daftar Rujukan}

[1] Marimin, Teori dan Aplikasi Sistem Pakar dalam Teknologi Manajerial. Bogor: IPB PRESS, 2007.

[2] D. D. Topik Purwanto, "Pengembangan sistem Pakar Diagnosis Penyakit Cabai," J. Algoritm., vol. 12, no. 1, 2015.

[3] S. Kusumadewi, teknik-dan-aplikasi-AI, Edisi Pert.
Yogyakarta: Graha Ilmu, 2003.

[4] E. Nugroho and M. Sulhi, "Sukses Budidaya Gurami di Lahan Sempit dan Hemat Air," in Sukses Budidaya Gurami di Lahan Sempit Dan Hemat Air, 2011: Penebar Swadaya, 2011.

[5] M. R. dan B. P. W. Julius Tirta Sendjaja, Usaha Pembenihan Gurami. Penebar Swadaya, 2011.

[6] B. S. M. Sitanggang, Budi Daya Gurami, XX. Jakarta: Penebar Swadaya, 2007.

[7] D. J. Perikanan, "Laporan Tahunan Direktorat Produksi 2013, Direktorat Jenderal Perikanan Budidaya, KKP," Jakarta, 2013.

[8] D. Priyambodo, "Pengaruh Pemberian Ekstrak Alga Cokelat (Padina sp) terhadap Kadar Hematokrit, Leukokrit, Aglutinasi dengan Bakteri dan Superoksida anion pada Ikan Gurami (Osphronemus Goramy)," Universitas Muhammadiyah Purwokerto, 2017.

[9] A. A. P. aristoteles, Wardiyanto, "Sistem Pakar Diagnosis Penyakit Pada Ikan Budidaya Air Tawar dengan Metode Forward Chaining," Media Infotama, vol. 3 , no. 2, p. 100, 2015.

[10] Lya Fikriyatul Azizah, "Sistem Pakar diagnosa Penyakit pada Ikan Gurame dengan Metode Forward Chaining Berbasis Android," Universitas Muhamadiyah Ponorogo, 2016.

[11] E. Yusnita and H. Aprilianto, "Sistem Pakar Diagnosa Penyakit Ikan Nila Menggunakan Dempster Shafer Berbasis Web," Jutisi, vol. 4, no. 2, pp. 789-796, 2015.

[12] M. Z. Muttaqin, E. Santoso, and B. Rahayudi, "Sistem Diagnosis Penyakit Ikan Koi Menggunakan Metode Forward Chaining dan Dempster-Shafer," J. Pengemb. Teknol. Inf. dan Ilmu Komput. Univ. Brawijaya, vol. 2, no. 8, 2018.

[13] T. Tumingan, Y. Yanitasari, and D. Dedih, "Sistem Pakar untuk Menentukan Penyakit Hernia dengan Menggunakan Metode Dempster-Shafer," Sisfo, vol. 06, no. 03, pp. 347-382, 2018.

[14] S. D. B. John W. Satzinger Robert B. Jackson, Systems Analisys \& Design in Changing Word, Fourth Edi. Canada, 2010.

[15] Shafer, G. A Mathematical Theory of Evidence, Princeton University Press, Princeton, NJ., 1976.

[16] Kusumadewi, S. Artificial Intelligence. Yogyakarta: Graha Ilmu, 2003. 